\title{
Low-Grade Fibromyxoid Sarcoma Arising in Posterior Nasal Cavity: Case Report and Review of the Literature
}

\author{
Jung Heob Sohn, Kijin Lee, and Kyoung Rai Cho \\ Department of Otorhinolaryngology-Head and Neck Surgery, Sanggye Paik Hospital, Inje University College of Medicine, Seoul, Korea
}

후비강에서 발생한 저등급의 섬유점액성 육종: 증례 보고 및 문헌 고찰

손정협 · 이기진 · 조경래

인제대학교 의과대학 상계백병원 이비인후과학교실

\author{
Received June 28, 2018 \\ Revised August 1,2018 \\ Accepted August 17, 2018 \\ Address for correspondence \\ Kyoung Rai Cho, MD, PhD \\ Department of Otorhinolaryngology- \\ Head and Neck Surgery, \\ Sanggye Paik Hospital, \\ Inje University College of Medicine, \\ 1342 Dongil-ro, Nowon-gu, \\ Seoul 01757, Korea \\ Tel $+82-2-950-1104$ \\ Fax $+82-2-935-6220$ \\ E-mail entr1@naver.com
}

Low-grade fibromyxoid sarcoma (LGFMS), a soft tissue tumor that has high recurrence and metastasizing potential, rarely occurs in the head and neck region. Therefore, the treatment for LGFMS in the facial area is challenging in terms of cosmetic and functional maintenance. The authors report a case of LGFMS in the posterior nasal cavity. It was completely removed in parallel with the nasal endoscopic and oral approach, but the lower margin was closed by preserving the soft palate. The patient is well without any recurrence or metastasis after 5 years of follow-up. Korean J Otorhinolaryngol-Head Neck Surg 2018;61(11):624-9

Key Words Low-grade fibromyxoid sarcoma · Nasal cavity · Sarcoma.

\section{서 론}

섬유점액성 육종(low-grade fibromyxoid sarcoma, LGFMS) 은 매우 드문 형태의 연부 조직 기원 종양이며, 조직학적으로 양성 소견을 보이는 것과 달리 국소 재발과 원격 전이의 빈도 가 높은 것으로 알려져 있다.) LGFMS는 연부조직육종(soft tissue sarcoma)의 $10 \%$ 정도의 비율을 차지하고 있으며, 주 로 체간과 하지 부위에 발생하고 비강 및 비부비동을 포함한 안면부 영역에서 발생하는 경우는 매우 드물다. ${ }^{2}$ 문헌 고찰 에 따르면, 현재까지 비강과 후사골동에서 각각 1 예가 발생 한 것을 포함하여 13예의 증례 보고가 이루어졌다.

LGFMS의 치료에 있어 가장 기본은 수술을 통한 병변의 완전 제거로 알려져 있다. ${ }^{34)}$ 그러나 비강 및 비부비동, 안면부

This is an Open Access article distributed under the terms of the Creative Commons Attribution Non-Commercial License (https://creativecommons.org/licenses/by-nc/4.0) which permits unrestricted non-commercial use, distribution, and reproduction in any medium, provided the original work is properly cited.
에서 발생한 LGFMS의 경우에는 발생 부위와 병변의 크기에 따라 충분한 수술 시야를 확보하기 어려울 수 있으며 수술 후 기능과 미용적 문제로 인해 충분한 안전 절제연을 확보하기 어렵다. 또한 보고된 증례가 많지 않고, 수술적 치료 후 1년 이내의 결과에 대한 보고가 대부분이므로 예후 인자, 수술의 접근 방식과 절제 범위, 술 후 방사선 치료나 항암화학요법의 필요성, 술 후 경과 관찰에 대한 정보가 전무하다고 볼 수 있 겠다. ${ }^{2)}$

저자들은 40세 여자 환자에서 후비강에 발생한 LGFMS 1 예에 대해 비내 접근법과 경구개 접근법을 병행하여 수술적 인 완전 절제를 시행하였으며 이후 보조적인 방사선 치료나 항 암화학요법 없이 5년간 경과 관찰하였기에 그 결과를 보고하 며, 또한 현재까지 보고된 증례들에 대한 문헌 고찰을 통해 비강 및 비부비동을 포함한 안면부에 발생한 LGFMS의 임 상 양상을 정리하여 함께 보고하는 바이다. 


\section{증 례}

40세 여자 환자가 2주 전부터 심해진 양측 코막힘을 주소 로 내원하였다. 환자는 예전부터 오른쪽 코막힘이 있었으나 왼쪽 코를 통한 호흡은 가능했다고 하며, 2주 전에 감기를 않 은 후 왼쪽 코막힘이 생기면서 양측 코로 숨을 쉴 수 없다고 하였다. 환자는 코막힘 외에는 다른 증상은 호소하지 않았으 며, 환자의 과거력에서 특이 사항은 없었다. 비내시경 검사에 서 비중격과 비강저 후방에서 기원한 것으로 보이는 매끈한 붉은색 종물이 양측 후비강을 완전히 막고 있는 소견이 관 찰되었다. 오른쪽의 경우에는 융기된 비강저 점막의 표면이 점액성 분비물로 덮여 비강을 채우고 있었다(Fig. 1). 비부비 동 전산화단층촬영 $(\mathrm{CT})$ 에서는 지름 $3 \mathrm{~cm}$ 으로 주변과 경계 가 비교적 명확하고 둥근 모양이며 균일하지 않은 조영 증강 을 보이는 연부 조직 종양이 비강 기저부에서 기원하여 양측 후비강을 막고 있었다. 또한 종괴와 맞닿아 있는 양측 하비갑 개와 중비갑개, 그리고 비중격의 골미란과 유착 소견이 확인
되었다(Fig. 2).

악성 종양의 가능성을 염두에 두었으나, 외래에서 내시경 을 이용한 조직 검사는 진단에 충분한 조직을 얻지 못하고 출혈의 위험성이 높을 수 있다고 판단하였다. 따라서 수술 결과에 따라 2 차 수술 등 추가 치료의 가능성을 환자에게 설 명하고 전신마취하에 조직학적 진단 목적을 포함한 병변의 절제를 시행하였다. 우선 비강 내부의 절제 범위를 결정하기 위해 내시경으로 비강을 확인하여 병변이 융기된 부위의 약 $1 \mathrm{~cm}$ 전방에서 양측에 비중격부터 비강 바닥까지 점막 절개 를 시행하였다. 골막하층을 따라 점막 피판을 들어 올려 병변 을 노출하였으며 병변이 유착되어 있는 서골(vomer)과 구개골 (palate bone)의 일부와 병변을 덮고 있는 비강 점막을 포함 하여 흡입 절삭기와 drill, Freer elevator를 이용하여 병변의 상부 경계에 대한 절제를 완료하였다. 비갑개를 포함한 비강 외측 벽은 병변의 침범 없이 단순히 융기된 비강 바닥 점막이 닿아 있는 양상이어서 절제 범위에 포함하지 않았다. 이후 구 강 접근을 통해 구개 점막에 U자 형태의 절개를 시행한 후
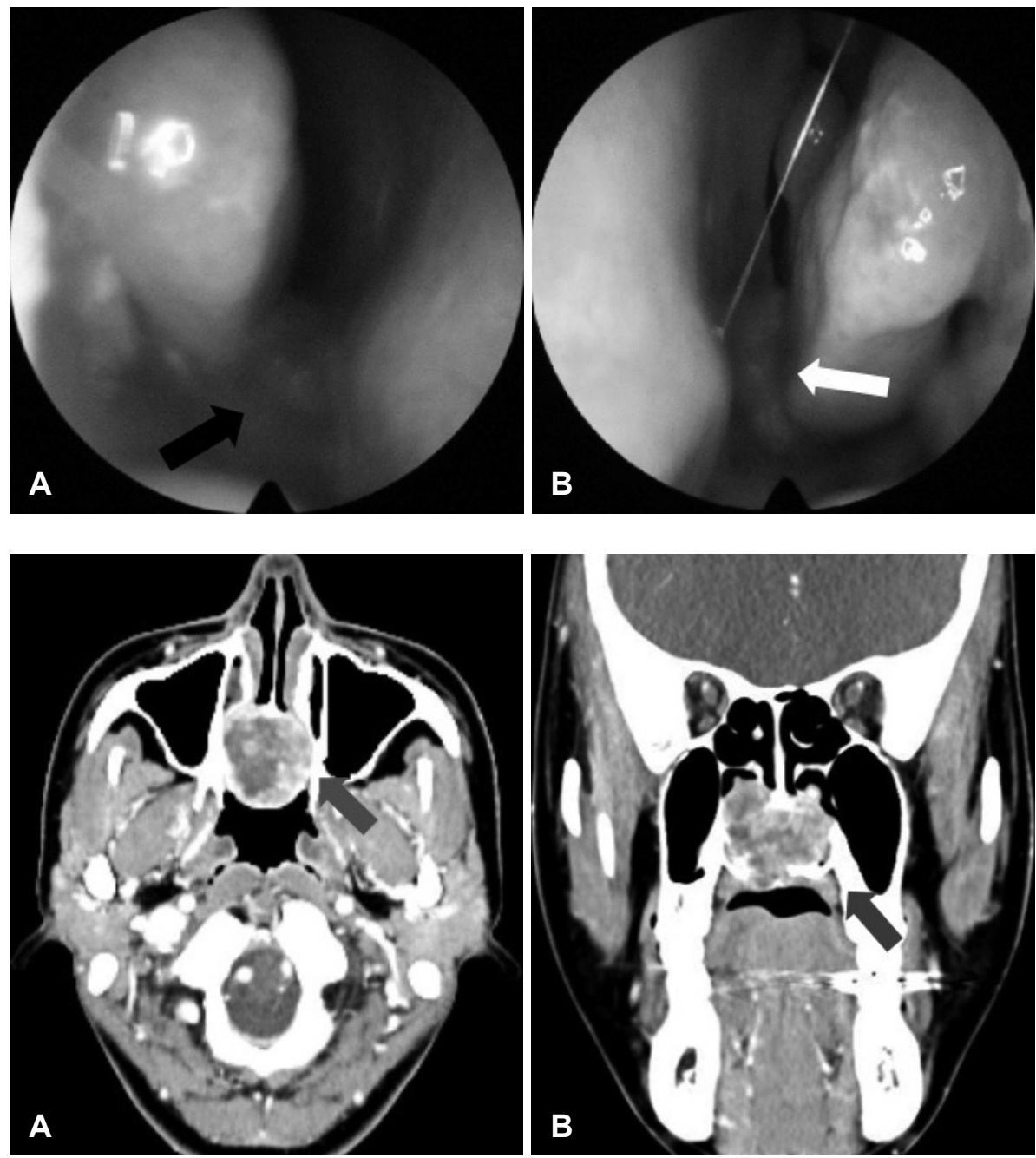

Fig. 2. Preoperative CT scans. CT showed a well-defined lobulated soft tissue mass $(3.3 \times 3.0 \times 3.3 \mathrm{~cm})$ with heterogeneous enhancement in posterior nasal cavity (arrows). Peripheral remodeling and erosion was suspected at nasal septum, hard palate and bilateral tubinates: axial (A) and coronal (B) images. 
점막 근육 피판을 들어 올려 병변의 하부 경계를 확인하고 병변을 완전히 절제할 수 있었다. 병변은 $3.5 \mathrm{~cm}$ 정도의 크기 로 일부에서 회색을 띈 갈색 연부 조직 병변이었고, 주변 연부 조직과의 유착은 심하지 않았으며 출혈도 많지 않았다. 절제 후 구개부의 점막 근육 피판은 다시 원위치에 놓고 봉합하였 으며, 비강 내부에는 양측 절제 부위를 얇은 실리콘 판(silastic sheet)을 삽입하여 덮어준 후 비중격에 고정하여 2주 동안 유 지하였다.

병리조직검사상 병변은 혈관 조직들이 교원성 기질(collag- enous stroma) 내부로 자라 들어가 얽혀 있는 사이로 세포가 적은 점액 조직이 주로 분포된 부위(hypocellular myxoid area)와 다수의 방추 세포가 주로 분포한 부위(hypercellular spindle cell area)가 혼재되어 축상(fascicular pattern)과 윤 상(whorled pattern)으로 자라는 소견을 보이고 있었다. 특히 교원성 기질에서 점액 조직(myxoid area)으로 이행되는 부위 에서 이러한 소견이 많이 관찰되었다(Fig. 3A). 병변의 중심 부는 교원 섬유에 의해 rosette을 형성하며, 주변에서 방추 세포와 조화를 이루어 구형과 난형의 세포들이 둘러싸고 있어
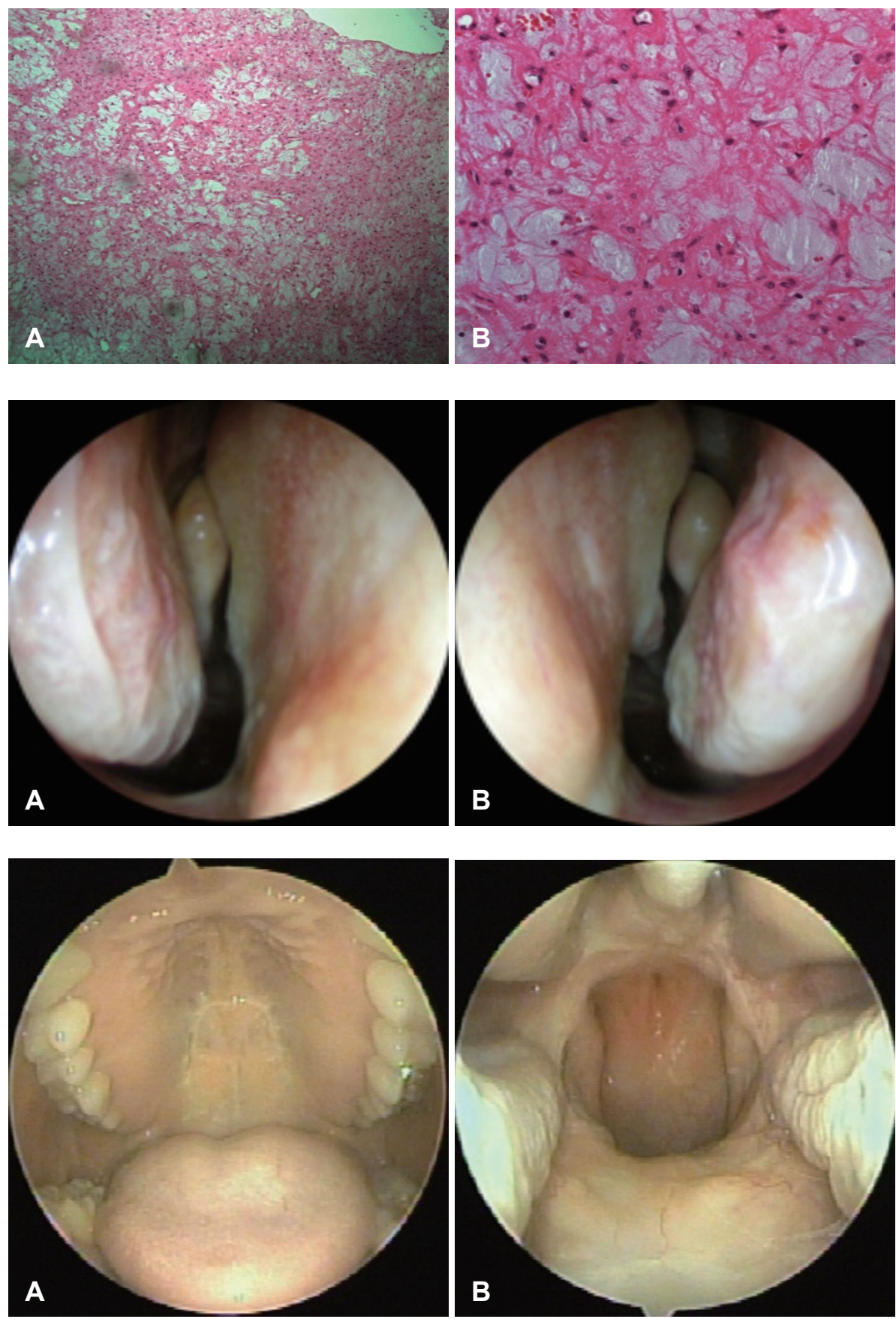

Fig. 5. Postoperative findings 5 years after surgery. It showed absence of any complication or recurrence $(\mathrm{A}$ : palate and B: posterior nasal cavity). 
(Fig. 3B), LGFMS로 진단하였다.

환자는 수술 후 1 개월간 비강 절제 부위에 악취를 동반한 가피가 반복적으로 형성되었으며, 경구 항생제와 비강 세척 을 유지하면서 외래에서 세심한 가피 제거와 드레싱을 시행 하였다. 이후 환자는 불편감을 호소하지 않았고 내시경에서 비강 소견도 양호하였다(Fig. 4). 수술 후 추가로 시행한 fluorodeoxyglucose $\left({ }^{18} \mathrm{~F}-\mathrm{FDG}\right)$ PET CT에서는 의미 있는 uptake는 확인되지 않았다. 안전 범위를 포함하여 병변이 완 전히 제거되었고 별다른 경부 전이나 원발 전이 소견이 보이 지 않아 방사선 치료를 포함한 추가적인 치료는 고려하지 않 았다. 다만 LGFMS가 국소 재발이나 원발 전이의 가능성이 높아, 이에 대해 환자에게 충분히 설명한 후 비내시경 검사 와 경부 진찰을 포함한 정기적인 추적 관찰을 시행하고 있다. 수술 후 5 년째 비강과 구강에서 재발이나 수술 후 합병증 소 견은 관찰되지 않으며(Fig. 5), 원격 전이 여부의 확인을 위해 시행한 ${ }^{18} \mathrm{~F}-\mathrm{FDG}$ PET CT에서도 병변의 절제 부위와 경부 에 재발을 시사하는 uptake는 확인되지 않았다.

\section{고 찰}

LGFMS는 1987년 Evans ${ }^{11}$ 에 의해 처음 보고되었으며, 섬 유성 기질과 점액성 기질이 혼재된 조직학적 활성도가 낮은 종양이다. 따라서 CT와 자기공명영상(MRI)에서 내부가 불균 일한 소견을 보인다. CT 영상의 경우 LGFMS는 주로 근육 조직의 심부에서 주변 근육 조직보다 저음영으로, 불균일한 조영 증강을 나타내며 일부에서 석회화를 동반하는 경우가 있다.5) 본 증례에서는 시행되지 않았으나, MRI는 다중 시퀀 스 영상을 통해 병변 내부의 섬유질 구성요소와 점액 구성요 소를 좀 더 뚜렷하게 구분할 수 있다. T2-weighted image에 서 특징적으로 병변 내부에 저강도 신호를 보이는 부위가 확인 되며, 최근에는 확산 강조 영상(diffusion weighted image) 을 병행하는 것이 진단에 도움을 준다는 보고가 있다.)

면역조직화학검사에서는 Vimentin, P53, bcl-2와 smooth muscle actin에 강한 양성을 보이고, cytokeratin-19, galectin-3에는 음성 소견을 보인다.) 점액섬유육종(myxofibrosarcoma)이 조직학적으로 유사한 소견을 보이지만 좀 더 균 일한 점액성 기질을 보이고 방추 세포들이 윤상으로 분포하 지 않으며, 원격 전이의 빈도에 있어 차이가 있으므로 감별이 필요하다. ${ }^{8)} \mathrm{LGFMS}$ 는 조직학적으로 양성의 소견을 보임에 도 불구하고 임상적으로 재발과 전이의 빈도가 높은 것으로 보고되고 있다."

주로 상하지나 체간에서 연부 조직에 발생하는 경우가 많 으며, 충분한 안전 범위를 확보하여 완전히 제거하는 것이 주
된 치료로 받아들여지고 있다. ${ }^{3)}$ 그러나 두경부 영역에서는 매 우 드물게 보고되고 있어서, 두경부 영역에서 발생한 LGFMS 는 치료 방법이나 치료 후 추적 관찰 기간에 대한 합의가 없 어 치료에 어려움이 있다.2,10) 특히 비강 및 비부비동을 포함 한 안면부에서 LGFMS가 발생하는 경우에는 안면부의 해부 학적인 복잡성으로 인해 충분한 병변의 절제를 위한 시야 확 보가 어렵고, 병변이 크거나 안와, 두개저를 침범한 경우에는 완전한 절제가 불가능할 수 있다. 또한 수술을 시행할 경우, 병변의 위치에 따라 수술 후 미용적인 문제와 코를 통한 호흡 이나 후각과 같은 기능적인 문제가 발생할 수 있어 절제 범위 를 결정하는 것이 쉽지 않다.

Pubmed와 Koreamed를 통해 "Low-grade fibromyxoid sarcoma" 혹은 "fibromyxoid sarcoma”를 검색어로 하여 확 인한 결과, 비강 및 비부비동에서 발생한 LGFMS는 지금까 지 총 2예가 보고되었다. 20세 남자 환자에서 발생한 증례 ${ }^{11}$ 는 좌측 후사골동(posterior ethmoid sinus)에서 기원하여 두 개저와 접형사골함요(sphenoethmoidal recess)에 이르는 병 변이었으며, 그 치료나 경과에 대한 정보는 확인할 수 없었다. 다른 예는 9세 남자 환자에서 좌측 상비갑개에 발생한 경우 로 비내시경 수술을 통해 절제한 경우였다. ${ }^{12)}$ 위의 두 예를 포 함하여 안면부에 발생한 경우는, 국외 문헌에서 1997년의 첫 보고 이후 현재까지 13개 문헌에서 13예가 보고되었고 국내 문헌은 확인된 바 없다. 저자들은 본 증례를 포함하여 문헌 고찰을 통해 확인한 총 14 예의 안면부의 LGFMS에 대해 논 문의 내용을 바탕으로 그 임상 양상을 정리하였다(Table 1).

성별은 남성에서 8예(57.1\%), 여성에서 6예(42.9\%)가 발생하 였으며, 진단 시 평균 연령은 30.1세(2 84세)로 20세 이하에서 진단된 경우가 7예(50.0\%)로 가장 많았다. 발생 부위는 전두부 가 1예(7.1\%), 상악 주변이 4예(28.6\%), 하악 주변이 3예(21.4\%), 이하선이 2예(14.3\%), 비강 및 비부비동이 3예(21.4\%), 구개 부 위가 1 예 $(7.1 \%)$ 로 확인되었다. 모든 경우에서 단일 종물의 형 태로 확인되었으며, 종물의 크기는 12 예에서 확인할 수 있었 다. 최대 지름을 기준으로 $1.3 \sim 17.0 \mathrm{~cm}$ 까지 그 크기가 다양 하였으며, 9예(64.3\%)에서 $4 \mathrm{~cm}$ 이하의 크기를 보이고 있었 다(평균: $5.0 \mathrm{~cm}$ ).

치료에 대한 정보를 알 수 있었던 13예에서는 모두 수술적 절제가 이루어졌으며, 4세 남아에서 하악(mandible)에 발생 하여 소파술(curettage)만 시행된 1예13)를 제외한 12예(92.3\%) 에서 완전 절제가 시행되었고, 그 중 1 예는 이하선에 발생한 $17 \mathrm{~cm}$ 크기의 종물로 절제술과 함께 방사선 보조요법이 시 행되었다. ${ }^{14)}$

국소 재발은 3 예 ${ }^{13,15,16}$ 에서 확인되었으며, 수술 후 재발하 기까지의 기간은 각각 24 개월, 3 개월, 15 개월이었다. 하악에 


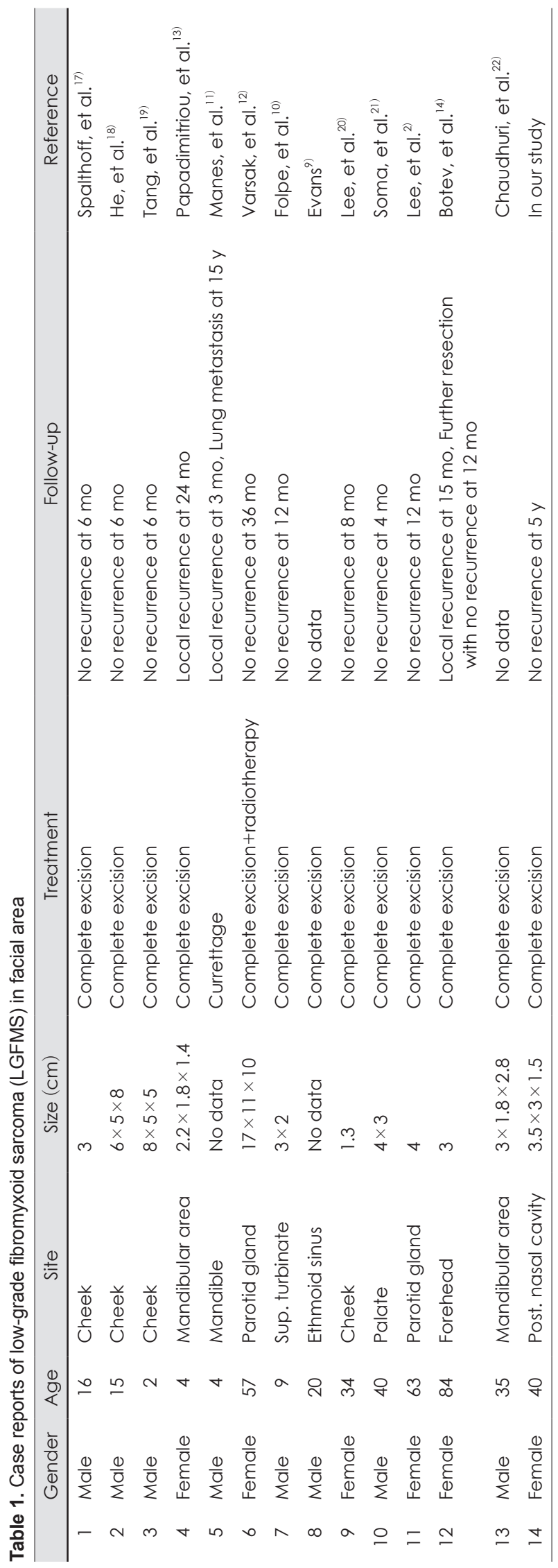

서 발생하여 소파술만 시행된 4세 남아의 증례에서는 치료 후 15 년이 경과하여 폐로의 원발 전이가 확인되었다. ${ }^{13)}$ 그런데 2예는 치료 후 경과 관찰에 대한 정보가 없었고, 5예에서는 치료 후 경과 관찰 기간이 1년 이하였다(4 8개월). 본 증례를 포함하여 적어도 2년 이상의 경과 관찰이 이루어진 경우는 5 예에 불과하며 이 중에서 3예에서 국소 재발이 확인된 점을 보았을 때, 안면부에 발생한 LGFMS의 국소 재발률은 상당 히 높다고 판단할 수 있겠다. 신체 여러 부위에서 발생한 33예 의 LGFMS에 대한 Evans ${ }^{9}$ 의 연구에서, LGFMS는 발생 부 위와 관계없이 높은 국소 재발과 원발 전이의 빈도를 보이고 있었다.

본 증례의 경우는 종물의 완전한 절제는 이루어졌으나, 종 물의 아래쪽 경계에서 구개 인두의 기능 유지를 위해 대부분 의 연구개 점막과 근육 조직을 보존함으로써 $1 \sim 1.5 \mathrm{~cm}$ 정도 의 안전한 절제 범위를 확보하지는 못하였다. 하지만 5 년 이 상 추적 관찰이 이루어졌고, 이를 통해 국소 재발이나 원격 전 이가 없음을 확인할 수 있었다. Evans'는 종물의 크기가 작고 첫 수술에서 제거한 종물의 절제연에서 종양 조직이 음성인 경우에 치료 결과가 더 좋을 것이라고 언급하였다. 좀 더 많은 증례를 통한 확인이 필요하겠으나, 종물이 완전히 절제되었고 수술 부위의 시야가 충분히 확보되어 추적 관찰 중에 국소 재 발 여부의 판단이 어렵지 않은 경우에는, 안면부의 LGFMS에 서 미용과 기능 유지 측면을 고려하여 수술 범위를 결정하는 것이 합당하다고 생각된다.

\section{REFERENCES}

1) Evans HL. Low-grade fibromyxoid sarcoma. A report of two metastasizing neoplams having a deceptively benign appearance. Am J Clin Pathol 1987;88(5):615-9.

2) Lee EJ, Hwang HJ, Byeon HK, Park HS, Chio HS. A low grade fibromyxoid sarcoma originating from the masseter muscle: a case report. J Med Case Rep 2015;9:176.

3) Evans HL. Low-grade fibromyxoid sarcoma. A report of 12 cases. Am J Surg Pathol 1993;17(6):595-600.

4) Vernon SE, Bejarano PA. Low-grade fibromyxoid sarcoma: a brief review. Arch Pathol Lab Med 2006;130(9):1358-60.

5) Hwang S, Kelliher E, Hameed M. Imaging features of low-grade fibromyxoid sarcoma (Evans tumor). Skeletal Radiol 2012;41(10): 1263-72.

6) Yue Y, Liu Y, Song L, Chen X, Wang Y, Wang Z. MRI findings of low-grade fibromyxoid sarcoma: a case report and literature review. BMC Musculoskelet Disord 2018;19(1):65.

7) Zamecnik M, Michal M. Low-grade fibromyxoid sarcoma: a report of eight cases with histologic, immunohistochemical, and ultrastructural study. Ann Diagn Pathol 2000;4(4):207-17.

8) Goodlad JR, Mentzel T, Fletcher CD. Low grade fibromyxoid sarcoma: clinicopathological analysis of eleven new cases in support of a distinct entity. Histopathology 1995;26(3):229-37.

9) Evans HL. Low-grade fibromyxoid sarcoma: a clinicopathologic study of 33 cases with long-term follow-up. Am J Surg Pathol 2011; 35(10):1450-62.

10) Folpe AL, Lane KL, Paull G, Weiss SW. Low-grade fibromyxoid 
sarcoma and hyalinizing spindle cell tumor with giant rosettes: a clinicopathologic study of 73 cases supporting their identity and assessing the impact of high grade areas. Am J Surg Pathol 2000;24 (10):1353-60.

11) Manes RP, Lemeshev Y, Batra PS. Pathology quiz case 2. Low-grade fibromyxoid sarcoma (LGFMS). Arch Otolaryngol Head Neck Surg 2011;137(2):198-202.

12) Varsak YK, Arbag H, Yesildemir HS, Esen H. Low-grade fibromyxoid sarcoma of superior turbinate in a pediatric patient. J Craniofac Surg 2015;26(3):962-4.

13) Papadimitriou JC, Ord RA, Drachenberg CB. Head and neck fibromyxoid sarcoma: clinicopathological correlation with emphasis on peculiar ultrastructural features related to collagen processing. Ultrastruct Pathol 1997;21(1):81-7.

14) Botev B, Casale M, Vincenzi B, D’Ascanio L, Santini D, Esposito V, et al. A giant sarcoma of the parotid gland: a case report and review of the literature. In Vivo 2006;20(6):907-10.

15) Wu X, Petrovic V, Torode IP, Chow CW. Low grade fibromyxoid sarcoma: problems in the diagnosis and management of a malignant tumour with bland histological appearance. Pathology 2009;41(2):
$155-60$.

16) Abe Y, Hashimoto I, Nakanishi H. Recurring facial low-grade fibromyxoid sarcoma in an elderly patient: a case report. J Med Invest 2012;59(3-4):266-9.

17) Spalthoff S, Bredt M, Gellrich NC, Jehn P. A rare pathology: lowgrade fibromyxoid sarcoma of the maxilla. J Oral Maxillofac Surg 2016;74(1):219.e1-10.

18) He KF, Jia J, Zhao YF. Low-grade fibromyxoid sarcoma with cystic appearance and osseous metaplasia in the cheek: a case report and review of the literature. J Oral Maxillofac Surg 2013;71(6):1143-50.

19) Tang Z, Zhou ZH, Lv CT, Qin LY, Wang Y, Tian G, et al. Low-grade fibromyxoid sarcoma: clinical study and case report. J Oral Maxillofac Surg 2010;68(4):873-84.

20) Lee JH, Choi HJ, Jung HY. Low-grade fibromyxoid sarcoma of the malar area. Arch Plast Surg 2016;43(1):110-2.

21) Soma $S$, Bhat $S$, Shetty SK. Low grade fibromyxoid sarcoma of the palate: a case report. J Clin Diagn Res 2015;9(10):XD01-XD02.

22) Chaudhuri K, Kasimsetty CR, Lingappa A, Gujjar PV. Low-grade fibromyxoid sarcoma involving the mandible: a diagnostic dilemma. J Oral Maxillofac Pathol 2016;20(2):334. 